\title{
Історичні основи запровадження процесу атестування військовослужбовців військових організаційних структур
}

\author{
В'ячеслав Косевцов * 1 А Вадим Машталір 2 в; Григорій Тіхонов ${ }^{3}$ А; \\ Олександр Білик 4 А \\ А Національний університет оборони України імені Івана Черняховського, м. Київ, України \\ В Генеральний штаб збройних Сил України, м. Київ, Україна
}

Received: November 5, 2021 | Revised: December 10, 2021 | Accepted: December 30, 2021

DOI: $10.33445 /$ sds.2021.11.6.3

\begin{abstract}
Анотація
У статті розглянуті теоретичні аспекти оцінки персоналу, історичні засади щодо даного питання, визначено місце оцінювання персоналу серед інших функцій управління персоналом. Досліджено роль та сутність поняття атестації, обґрунтовано необхідність проведення даної процедури, особливості організації та основні етапи їі проведення. Сформульовано пропозиції щодо підвищення ефективності організації оцінювання персоналу, удосконалення методів та процедур оцінки персоналу, запропоновано заходи щодо удосконалення оцінки за рахунок використання формалізовано-рейтингової системи атестації персоналу, яка широко застосовується у підприємницькій діяльності та окремих країнах НАTO.
\end{abstract}

Ключові слова: персонал, управління персоналом, оцінка персоналу, атестування.

\section{Постановка проблеми}

Bce більше підвищення бойових спроможностей військових організаційних структур та приведення їх до стандартів НАТО, подальше досягнення організаційних та індивідуальних цілей персоналом військових частин вимагає ефективного використання всіх ресурсів, що мають збройні сили i, насамперед, високої службової діяльності кожного члену військового колективу. Доволі зрозуміло, що персонал будь якої військової частини істотно розрізняються за своїми діловими та особистісними якостями, службовою поведінкою, рівнем виконаних службових обов'язків та наслідками діяльності. Для вирішення питання оцінки та подальшого більш ефективного використання персоналу історично проводиться робота з виявлення та оцінки можливостей кожного представника персоналу і на основі цього приймаються управлінські рішення його використання та застосується система оцінювання персоналу.

У 1911 році в одній з багаточисельних інструкцій Російської Імперії щодо проведення атестації підкреслювалось: “Система атестацій має на меті очистити армію від зайвих, непотрібних, і, як наслідок, шкідливих (у вольовому, розумовому чи фізичному плані) офіцерів, полегшити висування в перші ряди сильних і здібних" [3].

Так визначення суті оцінки та атестації офіцерських кадрів російської армії у другій половині XIX - на початку XX ст., визначило значні складнощі з ії̈ реалізації та результатів впровадження. Внаслідок проведеної роботи з середини XIX століття в армії Російській імперії була створена система атестування офіцерських кадрів, яка постійно вдосконалювалась і мала на меті підтримувати якість складу військових кадрів. Ця система мала

\footnotetext{
1 * Corresponding author: д.військ.н., професор, професор кафдри, e-mail: kosevtsov@ukr.net

2 д.істор.н., доцент, нач. управління ГШ ЗС України, e-mail: vadim_mashtalir@ukr.net

${ }^{3}$ к.військ.н., старший науковий співробітник, начальник кафедри, e-mail: tikhonov2404@ukr.net

${ }^{4}$ здобувач наукового ступеня, e-mail: alexanderbilyk@ukr.net
} 
стати засобом підвищення професійності офіцерських кадрів, стимулом їх росту i визначення резерву перспективних офіцерів. Саме в цей час були розроблені критерії оцінки якостей офіцера: воля, розум, талант, фізичний стан. Такий підхід сприяв висуванню офіцерів відповідно до їх характеру, умінь, знань.

Сучасний стан кадрової роботи у військових частинах яскраво показує приклади, коли старанні та відповідальні офіцери, з високими професійними якостями тривалий час були не поміченими керівним складом. Такі офіцери втрачають шанси на кар'єрне просування, їх вчасно не відмічають, хоча дійсно вони на це заслуговують, що яскраво показали наслідки антитерористичної операції та операції Об'єднаних сил на сході України де під час бойових дій було виявлено значну кількість достойних для просування офіцерів. У такій ситуації військова частина втрачає можливість ефективніше виконувати завдання.

Таким чином, серед багатьох складових роботи $з$ офіцерським складом насамперед посідає оцінка професійних, ділових якостей та організаторських здібностей офіцерів, їхніх можливостей виконувати службові обов'язки та функції на призначеній посаді. Якраз атестація, як найбільш поширена форма оцінки персоналу визначає рівень, кваліфікацію, знання, практичні навички, ділові якості персоналу і встановлення їх відповідності паспортам посад та виявлення їх потенційних можливостей.

Актуальність вивчення питань, пов'язаних з оцінкою та атестації персоналу у військовій організаційній структурі, обумовлена вирішенням проблеми підвищення ефективності управління персоналом, яке відіграє визначальну роль в підвищені бойових спроможностей військових організаційних структур та приведення їх до стандартів НАТО.

\section{Аналіз останніх досліджень та публікацій}

Питання оцінки та атестації персоналу досліджували багато вчених, зокрема: Балабанова Л.В. та Сардак О.В. [1], Виноградський М. Д., Виноградська А. М. та Шканова О.М. [2], Володина Н. Ю. та Иванова С.В. [4], Грішнова О.А. [5], Дмитренко Г.А., Шарапатова Е.А. та Максименко Т.М. [6], Іванісов О.В. та Доровський О. Ф. [7], Крушельницька О. В. та Мельничук Д.П. [8], Миронова Л. Г. [10], Сівашенко Т. [12].

Однак деякі аспекти атестації персоналу залишаються за межами досліджень i потребують подальшого розвитку. Варто було

\section{Постановка завдання}

На основі вищевикладеного можна сформулювати завдання дослідження, яке полягає в аналізі теоретичних та методологічних аспектів атестації персоналу у військовій організаційній структурі та розробці пропозицій щодо удосконалення процедури її проведення.
6 конкретизувати критерії оцінки персоналу для окремих військових організаційних структур, визначення основних методів та етапів при проведенні атестації на грунті існуючого досвіду останніх років тощо. Прийнятий Закон України “Про професійний розвиток працівників" [11] та велика кількість матеріалів щодо цих питань на практиці не дають певної визначеності щодо методики оцінювання персоналу деяких підприємств та застосування результатів цих оцінок в управлінській практиці для формування резерву керівників.

Метою статті $\epsilon$ аналіз сучасних особливостей оцінки якісних характеристик персоналу військової організаційної структури та її удосконалення за рахунок використання формалізовано-рейтингової системи атестації персоналу. 


\section{Виклад основного матеріалу}

Будь який командир військової організаційної структури на якомусь етапі своєї роботи рано чи пізно стикається з проблемою оцінки персоналу щодо підвищення бойових спроможностей та якості виконання військовою частиною навчально-бойових завдань. Адже для подальшого успішного розвитку військової організаційної структури, її стандартів та конкурентних переваг, необхідно постійно вдосконалюватися та знати свої перспективи, які в основному залежать від якості персоналу.

Призначення військовослужбовців на вищі посади [9] здійснюються за результатами комплексного оцінювання на підставі Резерву кандидатів для просування по службі.

Персонал $\epsilon$ головним ресурсом будь-якої організації та саме від його професійного розвитку, рівня кваліфікації, здібностей та вмінь залежить розвиток та ефективність виконання завдань військовою організаційною структурою. При цьому особливу увагу заслуговує оцінка спроможностей персоналу щодо його можливості управління саме у сфері управління персоналом. На даному етапі ці спроможності в основному оцінюються лише через наявність у людини документу про освіту на основі якої і робиться оцінка його можливостей у сфері управління персоналом. Але, на жаль, досить складно лише за документами про освіту визначити здібності персоналу до виконання службових обов'язків та його професіоналізм. Тому у військовій організаційній структурі потрібно застосовувати оцінку персоналу, яка буде відповідним критерієм професійних здібностей персоналу, показує особисті якості та перспективні можливості майбутніх офіцерів з питань управління персоналом та їх можливостей проявити свої лідерські якості. Об'єктивно проведена оцінка діяльності не тільки дасть змогу і можливість офіцеру мати уявлення про те, як буде оцінено виконання ним службових обов'язків, а й значною мірою впливає на мотивацію його дальшої службової діяльності.

Відповідно до цілей, завдань, елементів процесу оцінювання персоналу, можна зазначити, що побудова системи оцінки персоналу у військових організаційних структурах $є$ вкрай важливою й відповідальною справою. Дієвим способом виміряти результати роботи, рівень професійної компетенції офіцера та виявити його таланти $\epsilon$ система оцінювання персоналу. Оцінка персоналу - це цілеспрямований процес визначення відповідності якісних характеристик персоналу (здібностей, умінь, мотивів) вимогам паспорту посади. Оцінка персоналу передбачає порівняння певних характеристик людини - професійнокваліфікаційного рівня, ділових якостей, результатів праці з відповідними параметрами, вимогами, еталонами [8].

Для того, щоб оцінка персоналу була зрозумілою і мала мотиваційний характер, їі треба проводити за основним змістом діяльності, за тими ї̈ аспектами, які прямо пов'язані з виконанням службових обов'язків та їі результатами. Однак важливо оцінити і особисті якості офіцера, високий рівень яких $\epsilon$ передумовою ефективної службової діяльності.

Для того, щоб адекватно оцінити персонал військової організаційної структури необхідно для початку визначити перелік показників, які можна поділити на такі групи:

1) результативність службової діяльності;

2) професійність виконання службових обов'язків та виконання військової дисципліни;

3) особисті якості [7].

Розрахунок та визначення даних показників щодо об'єктивного оцінювання персоналу слід вимагає використання різноманітних методів, які повинні відповідати структурі військової організації, характеру службової діяльності персоналу, цілям оцінки. Сучасні фахові джерела виділяють цілу систему методів оцінки та основним у Збройних Силах України $€:$ атестація, що значно звужує систему оцінки 
персоналу та не дозволяє застосовувати сучасні методи оцінки, які широко застосовуються в передових країнах заходу, а саме: метод змушеного вибору, описовий метод, тестування, ділова гра, керування за цілями Management by Objective (MBO), управління результативністю - Performance management (PM), ассессмент центр (груповий і індивідуальний), самозвіт (виступ), метод $360^{\circ}$, оцінка методом комітетів, метод незалежних суддів, метод інтерв'ю, спостереження [1, 12].

Дані методики дозволяють проводити оцінювання персоналу як елемент управління і як система атестації персоналу, що, на нашу думку, повинна застосовуватися у військовій організаційній структурі в тій чи іншій модифікації в конкретний час оцінювання. У той самий час це необхідний засіб вивчення якісного складу кадрового потенціалу організації, його сильних і слабких сторін, а також основа для вдосконалення індивідуальних службових здібностей офіцера і підвищення його кваліфікації. Оцінка $€$ однією 3 функцій управління, за допомогою якої відбувається обгрунтування прийняття будьякого управлінського рішення [2].

На результатах ділового оцінювання персоналу базується рішення таких управлінських проблем:

- підбір персоналу;

- визначення ступеня відповідності займаній посаді;

- поліпшення використання персоналу;

- з'ясування внеску виконавців в результати роботи;

- просування офіцерів, необхідність підвищення кваліфікації;

- удосконалення структури апарату управління;

- удосконалення управління персоналом.

Оцінка персоналу передбачає порівняння певних характеристик людини - професійнокваліфікаційного рівня, ділових якостей, результатів службової діяльності 3 відповідними параметрами, вимогами, еталонами, а саме паспортом посади. Оцінювати персонал - це значить зробити висновок на основі порівняння “ідеального" виконавця (відповідності паспорту посади) 3 тим реальним офіцером, що виконує службові обов'язки В конкретній військовій організаційній структурі, на конкретній посаді. Оцінка персоналу полягає у визначенні того, якою мірою кожний офіцер досягає очікуваних результатів у виконанні обов'язків й відповідає тим вимогам, які випливають з паспорту посади відповідної для його виконання. Оцінка персоналу $\epsilon$ процедурою, яку проводять 3 метою виявлення міри відповідальності особистих якостей офіцера, кількісних і якісних результатів службової діяльності нормативним вимогам, поставленим цілям.

Разом з тим, лише атестація повинна давати право приймати будь-які кадрові рішення. Відповідно до прийнятого Закону України “Про професійний розвиток працівників" від 12.01.2012 № 4312-VI (зі змінами), під “атестацією” слід розуміти “процедуру оцінки професійного рівня працівників кваліфікаційним вимогам і посадовим обов'язкам, проведення оцінки їх професійного рівня" [11]. Відповідно до цього Закону атестаційна комісія на підставі усіх даних, за наявності не менше 2/3 ї членів, таємним або відкритим голосуванням приймає рішення про відповідність або невідповідність працівника займаній посаді або виконуваній роботі.

Атестування - це комплекс заходів з оцінки ділових та моральних якостей військовослужбовців, визначення їх відповідності посадам, перспектив службового використання та створення Резерву кандидатів для просування по службі та Плану переміщення військовослужбовців на посади.

Атестування повинне здійснюватися на принципах законності, прозорості, гласності та об'єктивності.

Основні завдання атестації щодо офіцера: визначення службової відповідності виконавця займаній посаді; виявлення перспективи використання потенційних здібностей і його можливостей; стимулю-вання росту професійної компетенції; визначення напрямів 
підвищення кваліфікації, професійної підготовки або перепідготовки; внесення пропозицій про переміщення кадрів, звільнення з посади, а також переведення на більш (чи менш) кваліфіковану роботу.

Атестування включає в себе дві процедури:

щорічне оцінювання службової діяльності військовослужбовців - це спостереження, вивчення і оцінювання службової діяльності військовослужбовців за визначеними критеріями діяльності і проявами якостей. Проводиться в кінці навчального року, за підсумками складається оцінна картка військовослужбовця. Результати щорічного оцінювання повинні відображати систематичне оцінювання результатів діяльності кожного військовослужбовця при виконанні ним функціональних обов'язків на посаді (посадах) впродовж року та за підсумками контрольних занять, підсумкових перевірок, інспектувань та ревізій;

періодичне атестування - це визначення перспектив подальшого службового використання. Проводиться перед закінченням строку дії контракту, перед закінчення строку перебування на посаді, перед закінченням військових навчальних закладів і науководослідних установ. За результатами періодичного атестування складається атестація. Періодичне атестування відбувається 3 обов'язковим урахуванням результатів, висвітлених в оцінних картках військовослужбовця за міжатестаційний період.

За підсумками щорічного оцінювання та періодичного атестування щодо військовослужбовців можуть прийматись відповідні кадрові рішення.

Організаційно проведення атестації оформлюється відповідним наказом, що додає їй офіційний статус і надає право на використання їі результатів для прийнятяя організаційних рішень у відношенні конкретного офіцера.

Взагалі потрібно підкреслити, що Атестація це завершений, документально оформлений результат оцінювання офіцера. Відповідальність за своєчасність проведення атестації покладається на управління військової організаційної структури, а безпосереднім виконавцем $\epsilon$ служба персоналу при активній участі керівників підрозділів.

Ефективність атестації зростає, якщо з нею пов'язані певні правові наслідки: заохочення, переведення на більш високу посаду, звільнення тощо. Тому за підсумками атестації видається наказ, яким затверджуються ії результати, рішення про зміни у рейтенгуванні та розставленні кадрів, про посадові оклади, зарахування перспективних офіцерів у резерв на підвищення, заохочуються позитивно атестовані офіцери тощо.

Результати атестації обговорюються на зборах офіцерів, нарадах, аналізуються підсумки атестації, дотримання порядку і умов іiі проведення, приймаються рішення щодо усунення виявлених недоліків.

Між тим, проведені авторами дослідження у військових організаційних структурах показують що досить важко військовій організаційній структурі з неефективною або неякісною системою оцінки персоналу досягти успіхів у виконанні завдань, що поставлені, оскільки, людський фактор, в більшій мірі, визначає успішність діяльності конкретної організації. Тому основне завдання, яке стоїть перед таким управлінням військової організаційної структури, полягає саме у вдосконаленні напрямків кадрової роботи. I це не лише завдання служби персоналу організації, воно повинно вирішуватися і на вищих рівнях управління.

На даний час оцінка персоналу не в повній мірі відповідає вимогам сьогодення та не в повній мірі адаптована до стандартів НАТО, а тому з метою підвищення ефективності оцінки якісних характеристик персоналу можна запропонувати вищому керівництву військових організаційних структур та службам персоналу удосконалену технологію проведення атестації персоналу. Для цього пропонується впровадити формалізовано-рейтингову систему атестації оцінки персоналу. Дана методика запропонована Іванісовим О.В. та Доровським О. Ф. [7] та широко застосовується 
в країнах НАТО.

У даній системі атестаційна (експертна) комісія складається 3 двох груп: групи адміністративної думки та групи колективної думки. Перша група характеризує офіцерів 3 точки зору вищого керівництва, друга - 3 позицій підлеглих і колег по роботі. Відповідно до процедури атестації персоналу, незалежно від технології її проведення, ті кого атестують, не запрошуються на засідання атестаційної комісії, оцінка їх якостей проводиться експертами за їх відсутності. Це дозволяє зняти психологічну напругу в колективі на період атестації. Однак за результатами атестації на засідання атестаційної комісії запрошуються ті особи, які отримали низькі рейтингові коефіцієнти якостей офіцера (у діапазоні від 0,2 до 0,49$)$, які говорять про те, що офіцер не відповідає займаній посаді. Особам, що отримали рейтингові коефіцієнти якостей від 0,50 до 0,59, призначається переатестація через рік. Особи, які отримали коефіцієнти від 0,60 до 0,80 (офіцер відповідає займаній посаді). Відомість результатів атестації доводиться до персоналу військової організаційної структури. Ті офіцери, у яких рейтинговий коефіцієнт виявився більше 0,8, повинні висуватися в резерв, призначатися на вищу посаду, ставати кандидатами на збільшення посадового окладу та премій.

Оцінку ділових і особистісних якостей офіцерів проводять за п'ятьма напрямками: службові якості, організаторські здібності, компетентність, особистісні якості, психологічна сумісність із колективом. Оскільки за своєю значимістю (важливістю) ці напрями неоднакові, кожен з них наділяється певною "вагою", яка визначається експертним шляхом методом математичного ранжування i попарного порівняння.

Практичним результатом проведеної атестації буде удосконалення системи оцінки персоналу у військовій організаційній структурі, яка дозволить підвищити як ефективність виконання службових обов'язків персоналу, так і ефективність діяльності усієї військової організаційної структури.
Відповідно до цієї технології були розроблені принципи та методика проведення атестації, спеціальна програма 3 підготовки проведення атестаційних заходів. Згідно даних можна отримати достовірну та об'єктивну інформацію на того чи іншого офіцера, оцінити рівень його підготовки, компетентність, відповідність займаній посаді, рівень знань тощо.

Алгоритм проведення формалізованорейтингової системи атестації у військовій організаційній структурі повинен бути наступним.

Першим етапом проведення атестації офіцера повинно стати формування експертної комісії, до складу якої включено керівника, його заступників та окремих начальників родів військ і сил. Оцінки офіцеру кожен експерт виставляє в оціночний лист за бальною системою відповідно до наступних критеріїв:

а) дана якість виявляється найвищою мірою і постійно - 5 балів;

б) дана якість виявляється практично постійно - 4 бали;

в) дана якість виявляється, але не досить часто - 3 бали;

г) дана якість не виявляється, але це не наносить збитку роботі - 2 бали;

д) дана якість не виявляється, і це завдає шкоди роботі - 1 бал.

Середня оцінка визначається як середнє арифметичне з вищенаведених показників за кожним критерієм. Потім всі оцінки приводяться до єдиного знаменника через співвідношення комплексної оцінки до максимально можливої величини. У зв'язку 3 цим вони будуть виражатися в частках одиниці, де одиниця - це норма, ідеал, стандарт (рівний 5 балам). У табл. 1 представлено фактори оцінки якостей офіцера.

При цьому вважається недоцільним збільшувати кількість показників, які будить другорядним типу "відношення до обслуговування техніки" тощо, що буде призводити до зниження можливих показників кращих офіцерів за головними показниками та підвищення показників слабких офіцерів. 
Таблиця 1 - Фактори оцінки якостей офіцера

\begin{tabular}{|c|l|c|c|}
\hline \multirow{2}{*}{$\begin{array}{c}\text { № } \\
3 / п\end{array}$} & \multicolumn{1}{|c|}{ Фактори оцінки } & \multicolumn{2}{|c|}{ Коефіцієнти значимості } \\
\cline { 3 - 4 } & & $\begin{array}{c}\text { для офіцерів- } \\
\text { керівників }\end{array}$ & $\begin{array}{c}\text { для офіцерів } \\
\text { спеціалістів }\end{array}$ \\
\hline 1 & Оцінка підрозділу, яким командує & 0,24 & 0,24 \\
\hline 2 & Організаторські здібності & 0,22 & 0,14 \\
\hline 3 & Компетентність & 0,18 & 0,26 \\
\hline 4 & Особистісні якості & 0,16 & 0,16 \\
\hline 5 & Психологічна сумісність з колективом & 0,20 & 0,20 \\
\hline \multicolumn{2}{|l}{ Усього } & 1,0 & 1,0 \\
\hline
\end{tabular}

Складено на прикладі: [7]

Таким чином, можуть бути отримані результати, виражені в рейтинговій системі 3 встановленням формальних меж, що чітко показують рівень офіцера, якого атестують, стосовно цих меж.

За даними оціночного листа проводиться поетапна процедура атестації, у можливій відповідності до шкали Харрінгтона:

1) в оціночний лист п'ять експертів проставляють оцінки за кожною якістю всіх п'яти факторів;

2) експертами визначається оцінка кожного фактору (середнє арифметичне сума балів кожного експерта за фактором);

3) корегується інтегральна оцінка фактору на відповідний коефіцієнт значущості (табл. 1):

4) визначається рейтинговий коефіцієнт співробітника (середнє арифметичне інтегральних оцінок, які скореговані на коефіцієнт значущості, усіх п'яти факторів).

За даною методикою пропонуються наступні значення рейтингового коефіцієнту:

а) від 0 до 0,19 - офіцер має бути звільнений;

б) від 0,2 до 0,49 - офіцер не відповідає займаній посаді;

в) від 0,5 до 0,59 - офіцеру призначається переатестація через рік з відповідними рекомендаціями щодо поліпшення служби, підвищення кваліфікації тощо;

г) від 0,6 до 0,8 - офіцер відповідає займаній посаді;

д) понад 0,8-офіцер може бути висунутий у резерв, який призначений на більш високу посаду, йому може бути збільшена заробітна плата [7].
Таким чином, система атестації офіцерів, у порівнянні з традиційною, більш об'єктивна у зв'язку з багатофакторним обліком різних якостей і участю в оцінці персоналу думки колег і підлеглих, що широко застосовується в країнах НАТО.

Практичним результатом проведеного дослідження повинно стати удосконалення системи оцінки персоналу у військовій організаційній структурі. Дана система дозволить підвищити, як ефективність виконання службових обов'язків персоналу, так і ефективність діяльності усій військової організаційної структури.

Для того, щоб система оцінки персоналу ефективно функціонувала, потрібно мати своєчасно та в достатній кількості необхідні ресурси. Ресурсне забезпечення оцінки персоналу представлене нормативноправовою та інформаційною базою, науковометодичним, кадровим, матеріальнотехнічним і фінансовим забезпеченням.

Робота 3 людьми, пов'язана 3 працевлаштуванням, переведенням чи звільненням з роботи, організацією оплати, підготовкою та підвищенням кваліфікації, регулюванням службового часу, створенням сприятливих умов служби, оцінюванням персоналу тощо, вимагає чіткої регламентації прав і обов'язків усіх учасників службових відносин. Це досягається шляхом використання відповідних законодавчих актів державного рівня та нормативно-правових i науково-методичних документів локального рівня (положень, норм, інструкцій, рекомендацій, характеристик тощо). 
Дослідження підтвердило думку про те, що відсутність достовірної та повної інформації, яка, у першу чергу, грунтується на комплексі документів нормативно-правового

\section{Висновки}

Атестація персоналу військової організаційної структури дає змогу оцінити рівень відповідності конкретного офіцера займаній посаді, а також оцінити виконувану ним роботу. Завдяки цьому у військовій організаційній структурі буде більш раціонально використовуватись наявний ресурсний потенціал. У системі ресурсного забезпечення присутні численні складові, забезпечення $€$ причиною прийняття неякісних рішень, які негативно впливають на ефективність функціонування системи оцінки персоналу.

\section{Список використаних джерел}

1. Балабанова, Л. В. \& Сардак, О. В. (2011). Управління персоналом. Київ: Центр учбової літератури, 468 с.

2. Виноградський, М. Д., Виноградська, А. М. \& Шканова О.М. (2009) Управління персоналом. Київ: ЦУЛ, 502 с.

3. Волков, С. В. (1993) Русский офицерский корпус. Москва, Воениздат.

4. Володина, Н. Ю. \& Иванова С.В. (2005) Оценка персонала. Москва, 110 с.

5. Грішнова, О.А. (2005) Оцінювання персоналу: сучасні підходи до забезпечення ефективності формування ринкової економіки. 3б. наук. праць, Т. 2. Київ: КНЕУ, 435 с.

6. Дмитренко, Г.А., Шарапатова, Е.А. \& Максименко, Т.М. (2002) Мотивація и оцінка персонала. Київ: МАУП, 248 с.

7. Іванісов, О. В. \& Доровський, О. Ф. (2012) Удосконалення системи оцінки персоналу за рахунок використання формалізованорейтингової системи атестації працівників на підприємстві. Комунальне господарство міст: Науково-технічний але, вони не повністю, хоча і в достатній мірі, забезпечують діяльність служби персоналу щодо оцінки конкретного офіцера. Деякі засоби матеріально-технічного та інформаційного забезпечення потребують оновлення чи розширення можливих функцій, що в свою чергу свідчить про недосконалість та незабезпеченість даними складовими забезпечення. збірник. № 106, с. 372-378.

8. Крушельницька, О. В. \& Мельничук, Д. П. (2003) Управління персоналом. Київ: Кондор, 296 с.

9. Методичні рекомендації 3 порядку формування і використання Резерву кандидатів для просування по службі у Збройних Силах України, затверджені директором Департаменту кадрової політики Міністерства оборони України від 19.03.2018 № $350 \quad$ (2019). URL: https://www.mil.gov.ua/content/other/mrk _rezerv_2019.pdf (дата зверн.: 10.11.2021)

10. Миронова, Л. Г. (2011) Сучасні методи оцінювання персоналу підприємств. Культура народів Причорномор'я, № 214. C. 46-50.

11. Про професійний розвиток працівників: Закон України від 12.01.2012p. № 4312VI (2012). Голос України, № 22.

12. Сівашенко, Т. (2011) Сучасні підходи до оцінки персоналу. URL: http://www.twirpx.com/file/1366161/ (дата зверн.: 10.11.2021).

\section{Исторические основы внедрения процесса аттестования военнослужащих военных организационных структур}




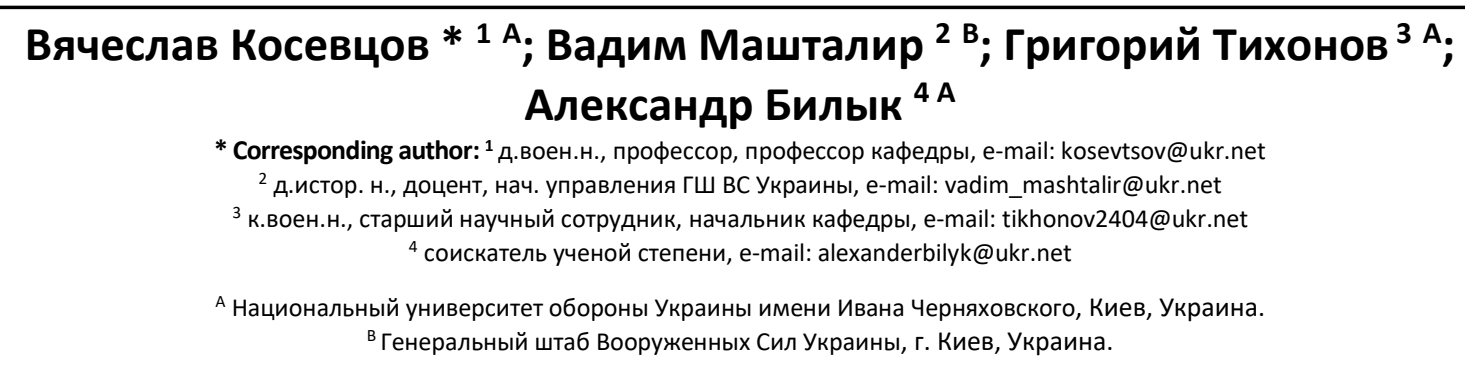

\begin{abstract}
Аннотация
В статье рассмотрены теоретические аспекты оценки персонала, исторические положения по данному вопросу, определено место оценивания персонала среди других функций управления персоналом. Исследованы роль и сущность понятия аттестации, обоснована необходимость проведения данной процедуры, особенности организации и основные этапы ее проведения. Сформулированы предложения по повышению эффективности организации оценки персонала, совершенствованию методов и процедур оценки персонала, предложены меры по усовершенствованию оценки за счет использования формализованно-рейтинговой системы аттестации персонала, широко применяемой в предпринимательской деятельности и отдельных странах НАТО.
\end{abstract}

Ключевые слова: персонал, управление персоналом, оценка персонала, аттестация.

\title{
Historical grounds of introduction of the process of certification of military servants of military organizational structures
}

\section{Vyacheslav Kosevtsov * 1 A; Vadim Mashtalir 2 B; Grigory Tikhonov ${ }^{3 \text { A; }}$ Aleksandr Bilyk ${ }^{4 \mathrm{~A}}$}

\author{
* Corresponding author: ${ }^{1}$ Dr, Professor, Professor of Department, e-mail: e-mail: kosevtsov@ukr.net \\ ${ }^{2}$ Dr, Associate Professor, Head of the Personnel Management Department of the Main Personnel Department, e-mail: vadim_mashtalir@ukr.net \\ ${ }^{3}$ Candidate of Military Sciences, Senior Researcher, Chief of Department, e-mail: tikhonov2404@ukr.net \\ ${ }^{4}$ Applicant for a scientific degree, e-mail: alexanderbilyk@ukr.net \\ A National Defence University of Ukraine named after Ivan Cherniachovskyi, Kyiv, Ukraine \\ ${ }^{B}$ General Staff of the Armed Forces of Ukraine, Kyiv, Ukraine
}

\begin{abstract}
The article deals with the theoretical aspects of personnel assessment, historical principles on this topic, identifies the place of personnel assessment among other functions of management of personnel. The analysis of: modern features of assessment of qualitative characteristics of personnel of military organizational structure and its improvement due to use of formalizedrating system of attestation of personnel, theoretical and methodological aspects of attestation of personnel in military organizational structure and development of offers on improvement of procedure of its implementation is carried out. The role and core of the concept of attestation are investigated, the necessity of carrying out this procedure, peculiarities of the organization and main stages of its carrying out are substantiated. There was defined the urgency of studying the issues related to the assessment and certification of personnel in the military organizational structure, due to the problem of improving the efficiency of personnel management, which plays a key role in improving the combat capabilities of military organizational structures and bringing them to NATO standards. There were formulated proposals for improving the efficiency of personnel assessment, improving methods and procedures for staff appraisal, and measures to improve appraisal through the use of a formalized rating system for staff appraisal, which is widely used in business and individual NATO countries.
\end{abstract}

Keywords: personnel, personnel management, personnel assessment, certification. 


\section{References}

1. Balabanova, L. V. \& Sardak, O. V. (2011). Upravlinnia personalom [Personnel management]. Kyiv: Tsentr uchbovoi literatury, $468 \mathrm{~s}$. [in Ukrainian].

2. Vynohradskyi, M. D., Vynohradska, A. M. \& Shkanova O. M. (2009) Upravlinnia personalom [Personnel management]. Kyiv: TsUL, 502 s. [in Ukrainian].

3. Volkov, S. V. (1993) Russkij oficerskij korpus [Russian officer corps]. Moskva, Voenizdat. [in Russian].

4. Volodina, N. YU. \& Ivanova S. V. (2005) Ocenka personala [Personnel assessment]. Moskva, 110 s. [in Russian].

5. Hrishnova, O. A. (2005) Otsiniuvannia personalu: suchasni pidkhody do zabezpechennia efektyvnosti formuvannia rynkovoi ekonomiky [Personnel evaluation: modern approaches to ensuring the effectiveness of market economy formation]. Zb. nauk. prats, T. 2. Kyiv: KNEU, 435 s. [in Ukrainian].

6. Dmytrenko, H. A., Sharapatova, E. A. \& Maksymenko, T. M. (2002) Motyvatsiia y otsinka personala [Motivation and evaluation of staff]. Kyiv: MAUP, 248 s. [in Ukrainian].

7. Ivanisov, O. V. \& Dorovskyi, O. F. (2012) Udoskonalennia systemy otsinky personalu za rakhunok vykorystannia formalizovanoreitynhovoi systemy atestatsii pratsivnykiv na pidpryiemstvi [Improving the system of personnel evaluation through the use of formalized-rating system of certification of employees at the enterprise]. Komunalne hospodarstvo mist: Naukovo-tekhnichnyi zbirnyk. № 106, s. 372-378 [in Ukrainian].

8. Krushelnytska, O. V. \& Melnychuk, D. P.
(2003) Upravlinnia personalom [Personnel management]. Kyiv: Kondor, 296 s. [in Ukrainian].

9. Metodychni rekomendatsii z poriadku formuvannia i vykorystannia Rezervu kandydativ dlia prosuvannia po sluzhbi u Zbroinykh Sylakh Ukrainy, zatverdzheni dyrektorom Departamentu kadrovoi polityky Ministerstva oborony Ukrainy vid 19.03.2018 № 350 (2019).

[Methodical recommendations on the order of formation and use Reserve of candidates for promotion in the Armed Forces of Ukraine, approved by the Director of the Personnel Policy Department of the Ministry of Defence of Ukraine dated March 19, 2018 № 350] (2019). Available from : https://www.mil.gov.ua/content/other/mrk _rezerv_2019.pdf [Accessed: 02.07.2021] [in Ukrainian].

10. Myronova, L. H. (2011) Suchasni metody otsiniuvannia personalu pidpryiemstv [Modern methods of evaluating the personnel of enterprises]. Kultura narodiv Prychornomoria, № 214, s. 46-50 [in Ukrainian].

11. Pro profesiinyi rozvytok pratsivnykiv: Zakon Ukrainy vid 12.01.2012r. № 4312-VI (2012) [On professional development of employees: Law of Ukraine of 12.01.2012 12 4312-VI]. Holos Ukrainy, № 22 [in Ukrainian].

12. Sivashenko, T. (2011) Suchasni pidkhody do otsinky personal [Modern approaches to personnel evaluation]. Available from: http://www.twirpx.com/file/1366161/ [Accessed: 02.07.2021] [in Ukrainian]. 